\title{
The Realization of the Principles of Conversation in the Teachers and Students' Speech in Indonesian Classroom Interaction
}

\author{
Andoyo Sastromiharjo*, Dian Anggraini Febtiani \\ Department of Indonesia Language Education \\ Universitas Pendidikan Indonesia \\ Bandung, Indonesia \\ *andoyo@upi.edu, diananggrainifebtiani@upi.edu
}

\begin{abstract}
The educative communication is essential to be noted since it is one of the components of teaching and learning activities in relation to the quality of educative communication constructed between the teacher and the student. The failure of achieving the learning objectives can be caused by the infringement of the conversation principles, not only in terms of cooperation principle but also politeness principle in the classroom interaction. Therefore, the realization of the conversation principles in the classroom interaction needs to be investigated to discover the interaction's strength in learning so that the competences can be achieved by the students effectively and efficiently. Through the recording of the teacher and students' speech in Indonesian classroom interaction of class $X$, it was found that there were adherence and infringement to the cooperation principle and politeness principle. The adherence to the cooperation principle occurred in maxim of quantity, maxim of quality, maxim of relevance, and maxim of manner. The infringement of cooperation principle occurred in maxim of relevance and maxim of manner. The adherence of politeness principle occurred in maxim of agreement, maxim of wisdom, maxim of sympathy, and maxim of appreciation. The infringement of politeness principle occurred in maxim of wisdom, maxim of appreciation, maxim of modesty, and maxim of agreement. Through the realization of the conversation principles in the classroom interaction, it can be concluded that the quality of educative communication affects the achievement of the learning objectives.
\end{abstract}

Keywords: classroom interaction, principles of conversation, adherence and infringement

\section{INTRODUCTION}

Educative interaction is an interaction that is occurred with the purpose of education and teaching [1]. Educative interaction in the classroom is included into normative interaction because teacher and students are undertaking the teaching and learning activities to achieve certain competence. In the process of learning interaction, there is a conversation performed by the teacher to the students and vice versa. According to Suryosubroto, one of the influential factors in educative interaction is the teachers themselves [2]. There are several factors from the teacher that affect the educative interaction, one of them is the way how the teacher talks. The way the teacher talks to the students has a huge impact, there are teachers who talk nervously, talk too fast, too soft, not well mannered, repetitive, and sometimes digress from subject topic. These issues will affect the interaction process of learning. Therefore, the language usage in the teacher's speech in learning interaction needs to be a particular concern because it has a central role in learning interaction, specifically in intellectual, social, and emotional development of the students. Educative interaction of learning requires a mutual understanding between the teacher and the students [3]. A research conducted by Febriana, et al indicates that the functions of the students' responsive speech toward the teacher's directive speech are acceptance, rejection, avoidance, complaint, information request, confirmation request, apology, and humor [4]. Evidently, the students' speech has power in the implementation of learning.

One of the relevant researches in relation to this topic is a research conducted by Lidanti, et al., yields a description of the adherence of cooperative principle, infringement of cooperative principle, adherence of politeness principle, infringement of politeness principle, and its implication toward the subject in language skills [5]. Another research by Hermaliza focused on the infringement of cooperative principle produced by host and the guest stars [6]. Moreover, Rakasiwi et al., focused on the implementation of cooperative principle and politeness principle toward the elementary school students' speech [7].

Verbal communication in language usage is known as speech. Studies of speech has been conducted since the emergence of performative utterances by John. L. Austin which was followed up with Speech Act Theory by J. R. Searle until H. Paul Grice who created the cooperative principle [8]. Currently, the study of speech is known as pragmatic. He explains that "pragmatic is the study of language usage". Based on that definition, studies or investigations toward language usage are included to studies of pragmatic. Yule further explains that this study involves the interpretation of actions 
actual facts), (3) Maxim of relevance, demanding the interactants to give a relevant contribution about something under discussion in order to establish a really good cooperation between the speaker and the speaking partners, and (4) Maxim of manner, demanding the interactants to deliver information directly, clearly, not vaguely, not cryptically, not taksa (not dubiously), and not complicatedly.

Therefore, this study aimed at analysing the implementation of cooperative principle in the teacher and students' speech is in Indonesian learning and the politeness principle in the teacher and students' speech is in Indonesian learning at Class X of Senior High School 5 Cimahi.

\section{MATERIALS AND MethoD}

The approach employed in this study is qualitative approach by using descriptive method to observe the teacher and students' speech in the learning interaction by describing the real condition. The data of the study are in a form of speeches produced by the teacher and students during the Indonesian learning at class X. There are two teachers involved in this study and class $\mathrm{X}$ as the site of data collection consists of two classes. This study is conducted by recording all of the teacher and students' speech in Indonesian learning interaction with handycam, voice recorder, and field notes.

\section{RESULTS}

Based on the result of the data analysis, the realization of conversation principle covers two things: (1) The adherence and infringement of politeness principle and (2) The adherence and infringement of cooperative principle.

\section{A. The Adherence and Infringement of Politeness Principle}

In the classroom interaction, the politeness principle between the teacher and students should include the adherence of its maxims. However, infringements toward its maxims is actually occurred. The result of the data analysis related to the politeness principle can be seen from the Table 1. It can be seen that the classroom conversation that concerns with the politeness principle, there are indications of adherences and infringements. The adherences of politeness principle are on the wisdom maxim, appreciation maxim, agreement maxim, and sympathy maxim. Maxim which is not occurred in the classroom interaction is generosity maxim and modesty maxim. The infringements of politeness principle are on the wisdom maxim, appreciation maxim, modesty maxim, and agreement maxim. and informative (explaining), (2) Maxim of quality, demanding the interactants to deliver something real or factual (based on

TABLE I. THE FREQUENCY OF THE ADHERENCE AND INFRINGEMENT DATA TOWARD THE POLITENESS PRINCIPLE

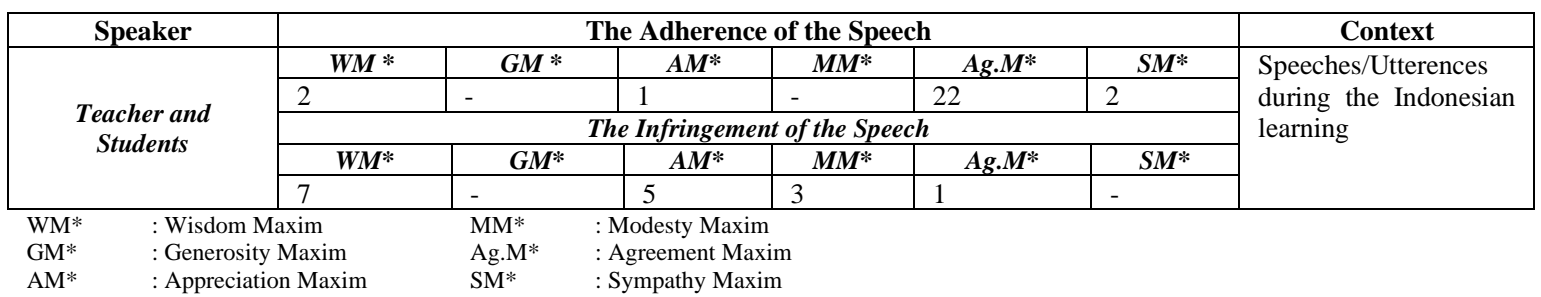


The description of the adherences and infringements of maxims in politeness principle can be seen from examples shown in Figure 1. The speaker and the speaking partner obey the agreement maxim. This is suitable with the politeness principle in agreement maxim that demands the interactants to show mutual agreement and compatibility toward the topic under discussion. It can be seen from the speech "Now, can you find the examples of persuasive paragraph and how to construct the paragraph. I give you 10 minutes. Later on, we will discuss it" the speaker intends to ask the speaking partner to look for materials about persuasive paragraph on the internet. The answer of the speaking partner is the speech "But, I don't have internet data in my phone" which intends to give an information to the speaker that he/she does not have internet data so that he/she is not able to look for the materials on the internet. In the speech "just use wifi", the speaker intends to ask the speaking partner to use the wifi provided by the school. The answer from the speaking partner are "no signal, maam" and "We need to go outside" which intend to give information to the speaker that the wifi provided by the school can be accessible from the outside of the classroom. In the speech "Ok, just do it in group, so you can share the data", it contains an adherence of agreement maxim because the speaker understand the obstacle encountered by the speaking partner, so that the speaker ask the speaking partner to look for the materials together. The speaker and speaking partner show mutual agreement about what is being discussed.

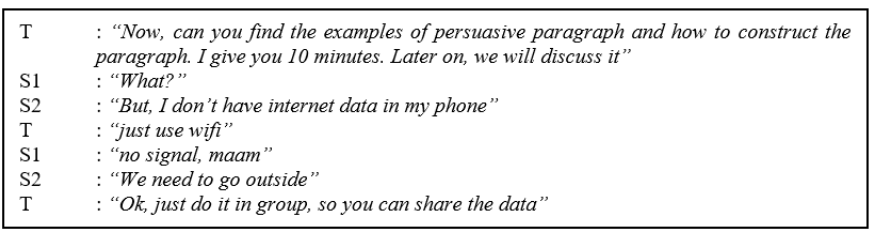

Fig. 1. Sample 1 of teacher-student interaction during lesson.

Other interaction (see Figure 2), the speaking partner disobey the wisdom maxim. It is not suitable with the politeness principle in wisdom maxim that demands the interactants to reduce self-benefits and maximize benefits for other people. In the speech "Which one (the task), Maam?", the speaker intends to ask the speaking partner about the location of the short story on the worksheet $(L K S)$. The answer from the speaking partner is "see the Hikayat si Miskin, just flip over (the page)", which intends to tell the speaker that the short story used in the task is entitled Hikayat Si Miskin and the short story is located on the opposite of the page. In the speech "Ouch, I am so not focus", the speaker intends to express that he/she does not feel focused so that he/she cannot find the short story. The answer from the speaking partner is "Your mind is always wandering around, thinking about X...", which contains an infringement toward the wisdom maxim because the speaking partner's response may be disadvantageous for the speaking partner by making him/her embarrassed because his/her friends are laughing at him/her.

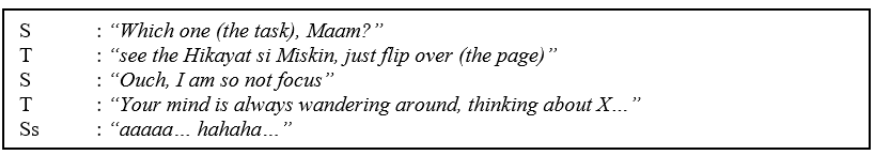

Fig. 2. Sample 2 of teacher-student interaction during lesson.

\section{B. The Adherence and Infringement of the Cooperative Principle}

A well-constructed and conducive classroom conversation is a conversation that encourage cooperative atmosphere between the teacher and the students. Therefore, an encouragement toward the cooperative principle should occur. However, the cooperative principle apparently does not always have maxims that are obeyed by either the speaker or the speaking partner. In terms of cooperative principle, the condition of the speech in the classroom conversation can be seen from the Table 2. The table shows that all of the maxims in the cooperative principle are obeyed by the speaker and the speaking partner. However, there are apparently infringements of the cooperative principle, which are on the maxim of relevance and maxim of manner. The data will be elaborated in details (see Figure 3).

TABLE II. THE FREQUENCY OF THE ADHERENCE AND INFRINGEMENTS DATA TOWARD THE COOPERATIVE PRINCIPLE

\begin{tabular}{|c|c|c|c|c|c|}
\hline Speaker & & he Adheren & the Speech & & Context \\
\hline \multirow{5}{*}{$\begin{array}{c}\text { The teachers and } \\
\text { Students }\end{array}$} & Maxim of Quantity & $\begin{array}{c}\text { Maxim of } \\
\text { Quality }\end{array}$ & $\begin{array}{l}\text { Maxim of } \\
\text { Relevance }\end{array}$ & $\begin{array}{c}\text { Maxim of } \\
\text { manner }\end{array}$ & \multirow{5}{*}{$\begin{array}{c}\text { Speeches/Utterences } \\
\text { during the } \\
\text { Indonesian learning }\end{array}$} \\
\hline & 85 & 30 & 41 & 19 & \\
\hline & \multicolumn{4}{|c|}{ The Infringement of the Speech } & \\
\hline & Maxim of Quantity & $\begin{array}{l}\text { Maxim of } \\
\text { Quality }\end{array}$ & $\begin{array}{l}\text { Maxim of } \\
\text { Relevance }\end{array}$ & $\begin{array}{c}\text { Maxim of } \\
\text { Manner }\end{array}$ & \\
\hline & - & - & 15 & 7 & \\
\hline
\end{tabular}

\begin{tabular}{|ll|}
\hline T & : "What is the English translation of "wawancara" (interview)? \\
S1 & : "Interview" \\
S2 & : "Interview" \\
S3 & : "Interview" \\
S4 & : "Interview" \\
\hline
\end{tabular}

Fig. 3. Sample 3 of teacher-student interaction during lesson.
From Figure 3, it is clear that the speaker and speaking partners obey the maxim of quantity. It is suitable with the cooperative principle in the maxim of quantity which demands the interactants to utter something that gives enough information, relatively adequate (fulfilling the needs), and informative (explaining). It can be seen from the speech "What is the English translation of 'wawancara' (interview)? The speaker intends to gather information about the term 
'wawancara' in English. The answer from all of the speaking partners is the speech "Interview" that contains the adherence of the maxim of quantity because the speaking partner can provide enough information in accordance with the question being asked and needed by the speaker without giving any excessive information.

Figure 4 shows that the speaking partner disobey the maxim of relevance. $t$ is not suitable with the cooperative principle in the maxim of relevance that demands the interactants to give contribution of relevant information about the things under discussion. It can be seen from the speech "So, let's not just talking about advancement. Be a part of it. One of them, let's keep our school clean, take care of the environment. Don't litter, it could lead to floods.", the speaker intends to advise the speaking partner to maintain the environment, one of the actions is not to throw garbages anywhere which can cause floods. The answer of the speaking partner is in the speech "“What about floods of tears?" which contains an infringement to the maxim of relevance because the speaking partner answer irrelevantly and digress from the context under discussion. 'flood of tears' does not have any relation to what is being discussed by the teacher.

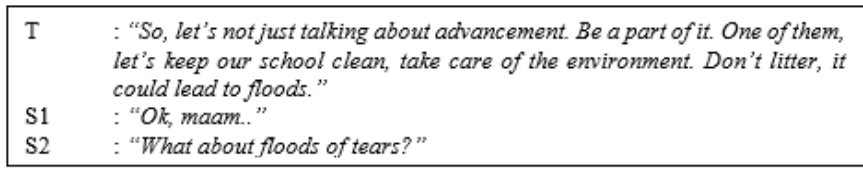

Fig. 4. Sample 4 of teacher-student interaction during lesson.

\section{DISCUSSION}

The communication between teacher and students in the learning class is essential to know the students' level of understanding toward the knowledge learned or the students' responses as learning feedback. That statement implies the importance of interaction in learning. The interaction of learning depends on the intensity level of speech between the teacher and students or among the students. Based on the data analysis, the real condition of the classroom interaction can be discussed. In Indonesian learning classroom interaction, it can be considered to have the politeness principle and cooperative principle. Both principles are merged in a context of educative conversation. However, in reality, between both principles, there are adherence and infringement. Among the maxims of politeness principle, agreement maxim is dominating in the context of learning. It proves that the learning is occurred democratically so that the competence may be achieved by the students. Furthermore, that condition indicates that all the transactions of interaction in learning are constructed well so that it can be a positive feedback [12]. Nevertheless, in politeness principle, there is a dominant infringement, which is, the wisdom maxim. This condition can be interpreted that the interaction of learning are undertaken in a disciplined condition. Discipline becomes one of the reinforcing factors in establishing the interaction of learning because this factor can strengthen the character building in education.

Cooperative principle built in the interaction of learning is dominated by maxim of quantity. This kind of condition indicates that the learning is undertaken in a high level of understanding. In other words, this condition indicates that the students are able to comprehend the knowledge learned. Therefore, the cooperative learning is running well [13]. In fact, according to Kemp, when the students are actively engaged with the interaction of learning, it is hoped that the students' learning results and retention can be enhanced and the learning activities will be more meaningful [13]. Admittedly, the interaction of learning in this cooperative principle can be interpreted as poor because the infringement of maxim of relevance are more than the manner maxim. On the one hand, this condition shows that the interaction of learning is negative because the teacher is less able to deliver the learning materials well. However, on the other hand, this condition can also shows a high level of creativity of the students.

\section{REFERENCES}

[1] A.M. Sardiman, Interaksi dan Motivasi Belajar Mengajar. Jakarta: Rajawali Press, 2011

[2] B. Suryosubroto, Proses Belajar Mengajar di Sekolah. Jakarta:Rineka Cipta, 2009.

[3] A. Chaer and L. Agustina, Sosiolinguistik sebagai Perkenalan Awal. Jakarta: Rineka Cipta, 2004

[4] S.I. Febriana, I. Suyitno, and H. Widodo, "Tuturan Responsif Siswa terhadap Tuturan Direktif Siswa”. Jurnal Online UM: jurnalonline.um.ac.id > data > .artikel

[5] F. Lidanti, N.E. Rusminto and W. Tarmini, "Penerapan prinsip percakapan dalam talk show bukan empat mata trans 7 dan implikasinya". Jurnal Kata. Lampung: Universitas Lampung, 2013.

[6] Hermaliza, "Pelanggaran prinsip kerja sama dalam tuturan ironi talkshow bukan empat mata trans 7: tinjauan pragmatik". Jurnal Bahasa. Riau: Universitas Riau, 2014.

[7] A.A.R. Rakasiwi, I.B. Putrayasa and I.N. Suandi, "Penerapan prinsip kerja sama dan prinsip kesantunan pada pembelajaran Behasa Indonesia dengan pendekatan saintifik oleh siswa kelas IV SD Jembatan Budaya. Jurnal Penelitian Pascasarjana UNDIKSHA. Denpasar: Universitas Pendidikan Ganesha, 2014.

[8] L. Mey, Jacob and R.E. Asher, Concise Encyclopedia of Pragmatics.Oxford: Elsevier Science Ltd, 1998.

[9] G. Yule, Pragmatik. Yogyakarta: Pustaka Pelajar, 2006.

[10] G. Leech, Prinsip-prinsip Pragmatik.Jakarta: Universitas Indonesia (UI) Press, 2011.

[11] Rustono, Prokok-pokok Pragmatik. Semarang: CV IKIP Semarang Press, 1999.

[12] M.K. Smith, Teori Pembelajaran dan Pengajaran. Terjemahan Abdul Qodir Shaleh.Yogyakarta: Mirza Media Pustaka, 2009.

[13] M. Wena, Strategi Pembelajaran Inovatif Kontemporer. Jakarta: Bumi Aksara, 2009. 